\title{
Interrelationship between Attachment Styles and Facebook Addiction
}

\author{
Yuksel Eroglu \\ Correspondence: Yuksel Eroglu, School of Education, Bayburt University, Bayburt, 69000, Turkey \\ Received: September 10, 2015 Accepted: September 28, 2015 Online Published: October 13, 2015 \\ doi:10.11114/jets.v4i1.1081 \\ URL: http://dx.doi.org/10.11114/jets.v4i1.1081
}

\begin{abstract}
Social networking sites have started to become one of the most frequently used online communication types in the world. It is reported that one of the commonly used social networking sites is Facebook. Since Facebook use is new yet, it can be stated that researches on the Facebook addiction are at the beginning level. For this reason, determining factors leading to the Facebook addiction has gained importance. In this context, in this study, relationships between attachment styles and the Facebook addiction were examined. The participants of the study were 322 university students $\left[145_{(45 \%)}\right.$ male, $177_{(55 \%)}$ female, $\mathrm{M}_{\mathrm{age}}=20.61$ years, $\left.\mathrm{SD}=1.82\right]$. In the study, the Personal Information Form, the Relationship Scales Questionnaire and the Facebook Addiction Scale were administered. The relationships between attachment styles and the Facebook addiction were calculated via using the Pearson correlation analysis. The Pearson correlation analysis results indicated that the Facebook addiction was negatively related with the secure and dismissing attachment style and positively related with the preoccupied attachment style. No relationship was found between the fearful attachment style and the Facebook addiction. If the attachment styles predicted the Facebook addiction was examined via using the stepwise regression analysis. The research findings indicated that the secure and dismissing attachment style negatively predicted and the preoccupied attachment style positively predicted the Facebook addiction. However, it was determined that the fearful attachment style did not predict Facebook addiction. The research findings were discussed under the light of related literature.
\end{abstract}

Keywords: attachment styles, facebook addiction, stepwise regression analysis

\section{Introduction}

\subsection{Facebook Addiction}

Social networking sites have become an indispensible part of the lives of many people. Social networking sites provide individuals with the opportunity to create profiles which are completely or partly open to public, add individuals with whom they want to establish communication in their lists of friends and establish communication with people whom they have added to their lists of friends in various ways (Boyd \& Ellison, 2007). Besides this, individuals can share their personal information, emotions, thoughts, photos and videos through social networking sites. Moreover, social networking sites provide individuals with many environments where they can entertain (Joinson, 2008).

Researchers report that one of the social networking sites commonly used throughout the world is Facebook. It was explained that the number of active Facebook users was 1.48 billion per month in the second quarter of 2015 (Facebook, 2015). Like other social networking sites, Facebook, too, provides many opportunities at the point of creating profiles, sharing personal information and establishing close relationships. In Facebook, individuals can establish communication with other individuals through status update, poking, sharing something on their walls and sending personal messages (Papacharissi \& Mendelsohn, 2011). Besides this, by using Facebook, individuals can set up groups or form activities, participate in formed groups and activities and tag their friends' photos (Foregger, 2008). Briefly, Facebook provides individuals with the opportunity to establish communication with their families and friends, helps them become aware of what is going on in the world and offers the possibility of expressing their own statuses (Facebook, 2015).

It is reported that there are many factors directing individuals to use Facebook. Researchers (Kim \& Haridakis, 2009; Oldmeadow, Quinn, \& Kowert, 2013; Papacharissi \& Mendelsohn, 2011; Satıc1 and Uysal, 2015) list these factors as entertainment, information search, spending time, self-presentation, socialization, meeting new individuals, surfing, escapism, status update and sexual attraction. It is reported that Facebook's including interactive activities achieving the fulfilment of such needs as self-presentation, entertainment, socialization and escaping may lead to addiction. It is observed that university students use Facebook mostly for maintaining their social relationships and establishing new 
social relationships (Hong, Huang, Lin \& Chiu, 2014; Kim, Sohn, \& Choi, 2011; Kuss, Griffiths \& Binder, 2013). In this direction, it can be stated that as individuals' need to maintain their online friendships increases, the possibility of becoming a Facebook addict increases (Hong et al., 2014). In conclusion, it is observed that the use of Facebook, achieving the fulfilment of various needs, may reach addiction level (Andreassen, Torsheim, Brunborg \& Pallasen, 2012; Kuss \& Griffiths, 2011).

Facebook addiction is defined as having difficulty in controlling and limiting the time spent in Facebook (Lee, Cheung \& Thadani, 2012). Moreover, Andreassen et al. (2012) list the symptoms of the Facebook addiction as mood modification, salience, tolerance development, withdrawal, conflict and relapse. Mood modification involves using social networking sites to create useful changes in an emotional. Salience involves one's giving all his/her attention to the use of social networking sites at cognitive, emotional and behavioral levels. Tolerance development covers extremely increasing the amount of using social networking sites. Withdrawal points to experiencing unpleasant physical and emotional symptoms when one cannot access social networking sites or is restricted to enter social networking sites. Conflict denotes living problems in home and work life, social relationships and other activities due to the use of social networking sites. Relapse points to one's not giving up using social networking sites although s/he tries to give up (Andreassen et al., 2012).

Kuss and Grififths (2011) stated that the Facebook addiction leads to psychological and social problems in an individual's life. Moreover, Facebook causes individuals to live problems in their school and work life. In the qualitative study carried out by Karaiskos, Tzavellas, Balta and Paparrigopoulos (2010), it was mentioned about a woman losing her job because of using Facebook for at least 5 hours a day. Sagioglou and Greitemeyer (2014) reported that Facebook affected individuals' emotional situations negatively. According to Sagioglou and Greitemeyer (2014), the reason for this is their not appreciating the value of time and thinking that they are busy with useless things in Facebook (Sagioglou and Greitemeyer, 2014). Kross et al. (2013) stated that the Facebook addiction decreases individuals' feelings of living the moment and their life satisfaction. Moreover, Bevan, Gomez and Sparks (2014) indicated that the Facebook addiction decrease individuals' life satisfaction. Besides this, there are also studies reporting that the Facebook addiction is associated with depression (Hong et al., 2014). The Facebook addiction's affecting all dimensions of individuals' lives seriously have directed researchers to investigate predictors of the Facebook addiction. In the literature, as the predictors of the Facebook addiction are emphasized personality, narcissism, low self-esteem, shyness, introvertedness and loneliness (Cao \& Su, 2007; Hughes, Rowe, Batey, \& Lee, 2012; Lavin, Yuen, Weinman \& Kozak, 2004).

\subsection{Attachment Styles}

The concept of attachment points out the natural tendency toward creating closeness and emotional attachment with important figures (Bowlby, 1977). It is stated that attachment relationships are based on basic figures formed in infancy and show themselves in adult life by going beyond childhood as well. Individuals create cognitive representations about themselves and others by encoding their early experiences which they live with basic attachment figures. Individuals' cognitive representations about themselves and others are called internally working models (Bartholomew \& Horowitz, 1991; Bowlby, 1980). Attachment schemes created in childhood affect individuals' perceptions, emotions and expectations in interpersonal relationships (Shaver \& Hazan, 1993) and are called adult attachment styles (Bartholomew and Horowitz, 1991). The model developed by Bartholomew and Horowitz (1991) in relation to adults' attachment styles includes four dimensions (secure, dismissing, fearful and preoccupied). This four-dimensional model is composed of the combination of individuals' negative and positive points of view about themselves and others (Bartholomew \& Horowitz, 1991).

It is stated that adult attachment is based on two basic dimensions, namely anxious and avoidance (Fraley, Waller, \& Brennan, 2000; Mikulincer \& Shaver, 2007). An individual's having both dimensions at low level indicates secure attachment. Securely attached individuals have positive internally working models about both themselves and others. These individuals feel secure in their close relationships, cope with stress actively and believe that other individuals will support them when they need (Mikulincer \& Florian, 1995). The anxious dimension includes extreme fear of rejection and the salient dimension includes using the strategies (hyperactiviting strategies) to achieve getting closer to others. The anxious dimension is characterized by negative view of self and oversensitivity to rejection and the salient is characterized by extremely focusing on others' reactions. The avoidance dimension is based on the rejection of the need for closeness and the salient covers suppressing behaviors related to getting closer to others (deactiviting strategies). In the avoidance dimension, having a negative view of other individuals, inhibiting the need for establishing relationships and emphasizing autonomy are mentioned (Mikulince \& Shaver, 2007).

Attachment styles affect how individuals perceive the world, how they react and how they cope with stressful situations resulting from interpersonal relationships. When the related literature is examined, it is observed that the attachment 
styles are discussed as an important regulator of an individual's behaviors (Mikulincer \& Shaver, 2007). For this reason, in studies made, it is eye-catching that many psychological constructs such as depression (Lee \& Koo, 2015), anxiety (Mikulincer \& Shaver, 2007), autism (Gallitto \& Leth-Steensen, 2015), eating disorders (Pepping, O'Donnovan, Zimmer-Gembeck, \& Hanisch, 2015), problematic internet use (Debernardi, 2012; Odacı \& Çıkrıkçı, 2014), antisocial behaviors (Oshri, Sutton, Clay-Warner, \& Miller, 2015) and burnout (Leiter, Day, \& Price, 2015) are discused as a function of individual differences in the attachment styles. In this context, Hart, Nailling, Bizer and Collins (2015) state that the attachment styles can be discussed as one of the individual factors accounting for individuals' cognitive, emotional and motivations based on their behaviors in social networking sites.

\subsection{Purpose of the Study}

Social compensation hypothesis (McKenna, Green, \& Gleason, 2002) puts forward that individuals having difficulty in establishing social relationships in real life tend towards online communication in order to meet these needs of theirs. Online communication provides individuals with many opportunities at the points of hiding identity, introducing themselves in any way they like and ignoring reactions of people with whom they establish communication. For this reason, it can be put forward that individuals having difficulty in establishing close social relationships may tend towards Facebook in order to meet these needs of theirs and this may result in addiction. In this context, in this study, it was hypothesized based on the social compensation theory that the Facebook addiction was negatively related with the secure attachment style and positively related with the dismissing, preoccupied and fearful attachment style (McKenna et al., 2002).

\section{Method}

\subsection{Research Model}

In this study, the relationships between the attachment styles and the Facebook addiction were examined based on the descriptive relational model. The data was collected from univesity students via using the measurement tools based on self-report. In the study, the cross-sectional model providing information about the current statuses of the participants was used.

\subsection{Participants}

In the study participated a total of 322 students, 145 male (45\%) and 177 female (55\%), taking education at the Education, Engineering, Economics and Administrative Sciences and Sciences and Arts faculties of Uludag University. 88 of the participants were the 1 st year (27\%), 69 were the 2 nd year $(21 \%), 74$ were the 3 rd year $(23 \%)$ and 91 were the 4 th year $(29 \%)$ students. The mean age of the participants aged between $18-33$ years old was found as $20.61 \pm 1.82$. Only the participants having a Facebook account was included in the study. The average weekly internet use of the participant individuals was found as $172.31 \pm 4.42$ hours.

\subsection{Data Collection Tools}

In the study, as data collection tools were used the Personal Information Form, the Relationship Scales Questionnaire and Bergen Facebook Addiction Scale.

\subsubsection{Personal Information Form}

In this form, there are questions about gender, age, class, average weekly internet use duration and having a Facebook account or not.

\subsubsection{Bergen Facebook Addiction Scale (BFAS; Andreassen et al., 2012)}

BFAS includes 18 items and individuals state the extent to which they agree to the items by using a Likert type grading varying from 1 (Very rarely to) to 5 (5: Very often). High scores obtained from BFAS indicate high Facebook addiction. The scale is composed of the sub-dimensions of salience, mood modification, tolerance, withdrawal, conflict and relapse. The reliability of the original form of the scale was found as .83. Its adaptation into Turkish was made by Akın, Demirci, Akın, Ocakcı, Akdeniz and Akbaş (2013). The findings obtained from the adaptation study (Akın et al., 2013) indicate that BFAS is a valid and reliable measurement tool which can be used in a Turkish sample with the purpose of measuring the Facebook addiction. The internal consistency reliability coefficient of the Turkish version of the BFA was determined as .93 (Akın et al., 2013).

\subsubsection{Relationship Scales Questionnaire (Griffin \& Bartholomew, 1994)}

In this study, with the aim of determining the participants' attachment styles, the Relationship Scales Questionnaire developed by Griffin and Bartholomew (1994) and adapted by Sümer and Güngör (1999) into Turkish was used. The Relationship Scales Questionnaire is composed of 17 items designed with the aim of measuring four attachment styles (secure, dismissing, fearful and preoccupied). The participants indicate their agreement levels for each item by using a 
7-point Likert type grading ( $1=$ does not define me in any way, 7=exactly defines me). According to the Relationship Scales Questionnaire, a participant is evaluated as having an attachment style if they get a high score from that attachment style. In the validity and reliability study which Sümer and Güngör (1999) carried out in a Turkish sample, they determined that the scale, similarly to its original form, was composed of four sub-dimensions, namely secure, dismissing, preoccupied and fearful attachment styles. Sümer and Güngör (1999) examined the reliability of the scale by using both the Cronbach's alpha internal consistency coefficient and the test-retest reliability. In their study, Sümer and Güngör (1999) determined that the test-retest reliability coefficients of the scale varied between .54 and .78 and the internal consistency coefficients varied between .27 and .61. In other studies made in Turkey (Arslan, Arslan, \& Ar1, 2012; Deniz, 2006; Gündüz, 2013; Ilhan, 2012; Odacı and Çıkrıkçı, 2014; Şimşek, 2011), too, it was observed that the internal consistency coefficients of the sub-scales were at low level. Griffin and Bartholomew (1994) stated that this resulted from the sub-scales' including the model belonging both to self and others together. Griffin and Bartholomew (1994) indicated that although the internal coefficients of the sub-scales were low, their construct validities were at sufficient level.

\subsection{Data Collection}

The data was collected in the 2014-2015 academic year. Before participating in the study, the participants were informed about the purpose of the study and the participation in the study was based on voluntariness. Moreover, they were told that they could leave the study whenever they wanted. The measurement tools were administered to the participants in the classroom environment. In the selection of the participants, the convenience sampling method was used. The convenience sampling method includes selection of participants providing the researcher with convenience in terms of time and accessibility.

\subsection{Data Analysis}

In the examination of the relationships between the attachment styles and the Facebook addiction, the Pearson correlation coefficient and the stepwise regression analysis were used. Before employing the stepwise regression analysis, the hypotheses were checked. In the multiple regression analysis, the total scores obtained by the participants from the BFAS were used as the dependent variable and those obtained from the sub-dimensions of the Relationship Scales Questionnaire (secure, preoccupied, fearful and dismissing) were used as the independent variable.

\section{Results}

\subsection{Descriptive Statistics and Zero-order Correlations}

The descriptive statistics belonging to the variables used in the study and the Pearson correlation coefficients between the variables were shown in Table 1.

Table 1. Descriptive statistictis and zero-order correlations between attachment styles and Facebook addiction

\begin{tabular}{|c|c|c|c|c|c|}
\hline Variables & 1 & 2 & 3 & 4 & 5 \\
\hline 1.Facebook addiction & & & & & \\
\hline 2.Secure attachment style & $-.39^{* *}$ & & & & \\
\hline $\begin{array}{l}\text { 3.Dismissing } \\
\text { attachment style }\end{array}$ & $-.18^{* *}$ & -.03 & & & \\
\hline 4.Preoccupied attachment style & $.15^{* *}$ & -.03 & $-.19^{* *}$ & & \\
\hline 5.Fearful attachment style & .08 & $-.24^{* *}$ & $.29^{* *}$ & .03 & \\
\hline Mean & 42.30 & 20.23 & 22.06 & 15.52 & 15.22 \\
\hline Standard Deviation & 15.56 & 4.46 & 4.65 & 3.74 & 4.49 \\
\hline
\end{tabular}

$* * \mathrm{p}<.01$

When Table 1 is examined, it is observed that the participants' Facebook addictions were at average level $(\mathrm{M}=42.30$,

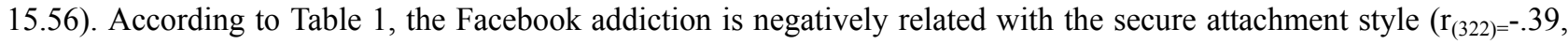
$95 \%$ C. I. $[-.48,-.29]$ and the dismissing attachment style $\left(\mathrm{r}_{(322)}=-.18, \%\right.$ C. I. $[-.28,-.07]$ and positively related with the preoccupied attachment style $\left(\mathrm{r}_{(322)=} .15, \%\right.$ C.I. $[.04, .25]$.

Scatter diagrams of Pearson correlations of Facebook addiction to the secure, dismissing, preoccupied, and fearful attachment styles were shown in Figure 1, 2, 3, and 4. 


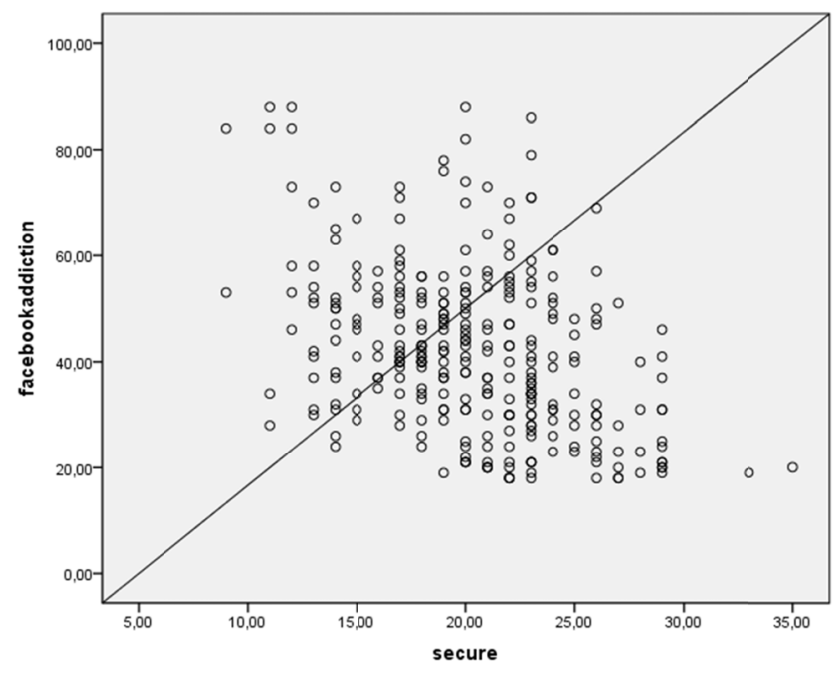

Figure 1. Scatter diagram of Pearson correlation between secure attachment style and Facebook addiction

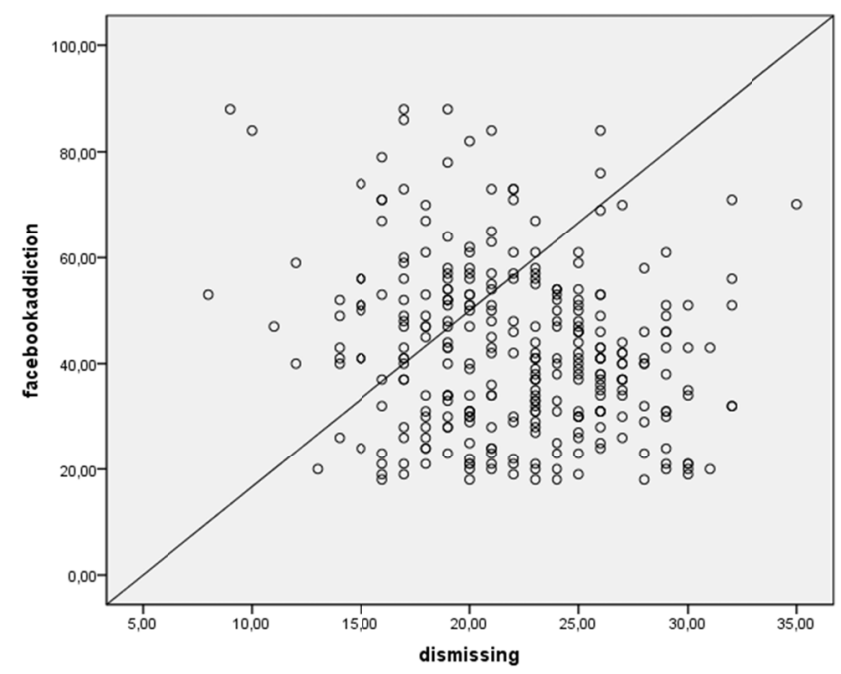

Figure 2. Scatter diagram of Pearson correlation between dismissing attachment style and Facebook addiction

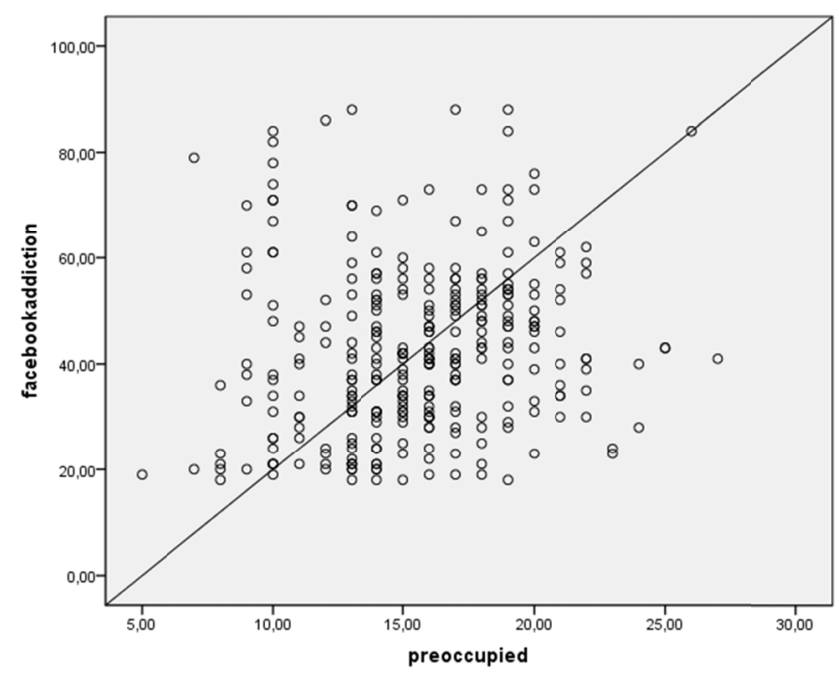

Figure 3. Scatter diagram of Pearson correlation between preoccupied attachment style and Facebook addiction 


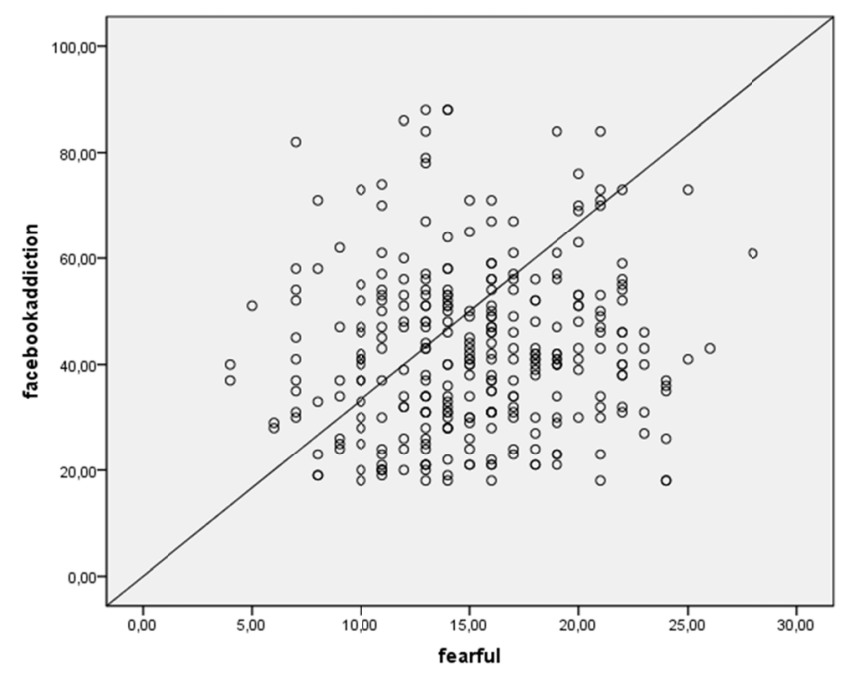

Figure 4. Scatter diagram of Pearson correlation between fearful attachment style and Facebook addiction

\subsection{Multiple Regression Analysis}

Before employing the multiple regression analysis, the hypotheses were checked. If the variables distributed normally or not was examined by using the Kolmogorov-Smirnov test. The Kolmogorov-Smirnov test indicated that all the variables taken into the multiple regression analysis distributed normally. The results of the Kolmogorov-Smirnov test were found as $.20(p>.05)$ for the Facebook addiction, .15 ( $>$ >05) for the secure attachment style, $.08(p>.05)$ for the fearful attachment style, .11 (p>.05) for the preoccupied attachment style and .10 ( $>>.05)$ for the dismissing attachment style. Moreover, it was observed that the skewness and kurtosis coefficients belonging to all the variables taken into the multiple regression analysis varied between -1 and 1 . If there was a multicollinearity problem was examined by using the variance inflation factor (VIF). That all the VIF values were smaller than 10 (Tabachnick and Fidell, 2001) indicated that there was not a collinearity problem. The results belonging to the multiple regression analysis where the attachment styles were the predictive and the Facebook addiction was the predicted variable were given in Table 2.

Table 2. Stepwise regression analysis for Facebook addiction

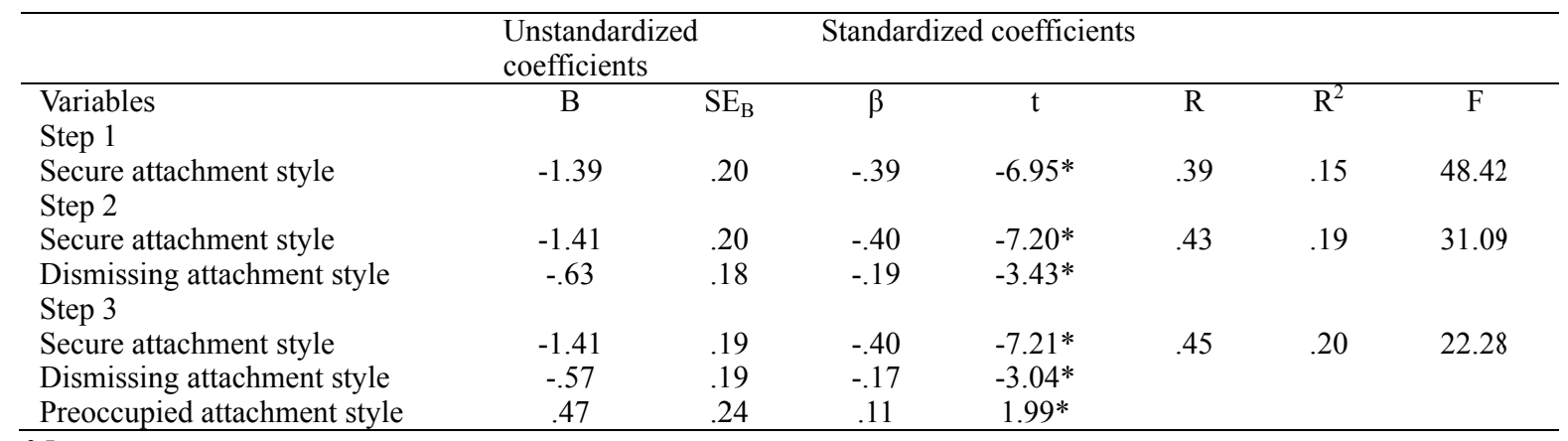
$* \mathrm{p}<.05$

According to Table 2, firstly the secure attachment style entered the regression equation and accounted for $15 \%$ of the Facebook addiction, $\mathrm{R}^{2}=.15$, Adjusted $\mathrm{R}^{2}=.15, \mathrm{~F}(1,268)=48.42, \mathrm{p}<.05$. In the second stage of the multiple regression analysis, the dismissing attachment style was added to the regression analysis. The dismissing attachment style accounted for $4 \%$ of the Facebook addiction, $\mathrm{R}^{2}=.19$, Adjusted $\mathrm{R}^{2}=.18, \Delta \mathrm{R}^{2}=.04, \mathrm{~F}(2,268)=31.09, \mathrm{p}<.05$. In the last stage of the regression equation, the preoccupied attachment style took place in the regression equation, $R^{2}=.20$, Adjusted $\mathrm{R}^{2}=.19, \Delta \mathrm{R}=.01, \mathrm{~F}(3,268)=22.28$. The preoccupied attachment style made a contribution of $1 \%$ to the variance belonging to the Facebook addiction. The secure, dismissing and preoccupied attachment styles together accounted for $20 \%$ of the Facebook addiction. The Cohen's $f^{2}$ coefficient related to this accounting rate was found as .25. Based on this coefficient, it can be stated that the secure, preoccupied and dismissing attachment styles together have a moderate effect on the Facebook addiction (Cohen, 1988). Although the fearful attachment style was taken into the regression equation at the beginning, it was observed that it did not predict the Facebook addiction. When the standardized coefficients indicating the relative order of importance of the variables were examined, it was determined that the independent variable having the strongest effect on the Facebook addiction was the secure attachment style $(\beta=-.40, \mathrm{t}=-7.21, \mathrm{p}<.05)$ and this was followed in order by the dismissing $(\beta=-.17, \mathrm{t}=-3.04, \mathrm{p}<.05)$ and preoccupied 
$(\beta=.11, \mathrm{t}=1.99, \mathrm{p}<.05)$ attachment styles. According to the standardized coefficients, the strongest predictor of the Facebook addiction was the secure attachment style.

\section{Discussion}

In this study, the relationships between the attachment styles and the Facebook addiction were examined. The research results indicated that the Facebook addiction was negatively predicted by the secure and dismissing attachment styles and positively predicted by the preoccupied attachment style. Moreover, it was determined that the strongest predictor of the Facebook addiction was the secure attachment style and this was followed in order by the dismissing and the preoccupied attachment styles.

In this study, it was observed that the strongest predictor of the Facebook addiction was the secure attachment style. According to the research findings, as the participants' secure attachment style scores increase, their Facebook addiction scores decrease. Individuals with secure attachment style have positive perceptions about themselves and others. These individuals perceive themselves as those who are worth loving and honest. Moreover, they trust themselves and behave assertively in social environments. Besides this, when individuals with the secure attachment style experience a problem, they believe that they will get sufficient support from other individuals (Huntsinger \& Luecken, 2004; Hazan \& Shaver, 1987). Park, Crocker and Mickelson (2004) stated that individuals with the secure attachment style can establish supportive social relationships in real life thanks to these characteristics of theirs. Starting from here, it can be stated that the ability to establish satisfying social relationships in real life will protect individuals with the secure attachment style against the Facebook addiction. The finding obtained in the study carried out by Satıc1, Sarıcalı, Satic1 and Eraslan-Çapan (2014) that the social sufficiency predicted the Facebook addiction negatively supports this interpretation.

In this study, that the dismissing attachment style predicted the Facebook addiction in a negative way can be evaluated as an interesting finding. This finding contradicts the studies reporting that the individuals with the dismissing attachment style are at risk in terms of problematic internet use (Debernardi, 2012; Lin, Ko, \& Wu, 2011; Odac1 \& Çıkrıkçı, 2014). According to the mentioned researchers, that individuals with the dismissing attachment style live approaching anxiety leads to social incapability in them and this results in problematic internet use. Individuals with the dismissing attachment style self-regard excessively, attach very much importance to self-efficacy and prefer to withdraw from other individuals affectively (Shaver \& Hazan, 1993). For this reason, it can be stated that individuals with the dismissing attachment style tend to withdraw from environments where they think that their self-efficacies are threatened. In the recent period, some researchers (Chou \& Edge, 2012; Gulati, 2011) have emphasized the fact that Facebook trigger social comparison and create a competition-based online culture. In conclusion, it can be stated that individuals with the dismissing attachment style may withdraw from Facebook when they think that their self-efficacies are damaged because of social comparisons.

In this study, it was found that the preoccupied attachment style predicted the Facebook addiction in a positive way. In other words, as the participants' preoccupied attachment style scores increase, their Facebook addiction increase. Individuals with the preoccupied attachment style feel themselves worthless. However, individuals with the preoccupied attachment style have positive opinions about other individuals. For this reason, individuals with the preoccupied attachment style are in need of receiving positive feedback from other individuals in order to feel themselves worthy (Brennan \& Bosson, 1998). Facebook's including many applications including receiving positive feedback and manage other individuals' impressions (for example, the alternatives of "like" and "comment") may put individuals with the preoccupied attachment style at risk in terms of Facebook addiction. Moreover, another reason why individuals with the preoccupied attachment style are at risk in terms of Facebook addiction might be Facebook's including features facilitating the establishment of social relationships (for example, possibility of an individual's introducing him/herself differently in order to get the approval of party) (Hart et al., 2015).

In this study, it was determined that the fearful attachment style was not related with the Facebook addiction. Individuals with the fearful attachment style have negative perceptions about both themselves and other individuals. They think they are not worth loving. Moreover, they desire to establish social relationships with other individuals, but they are oversensitive to being rejected by others (Bartholomew \& Horowitz, 1991). The social compensation hypothesis (McKenna et al., 2002) states that individuals use social networking sites to compensate their insufficiencies in real life. For example, in the study carried out by Hong et al., (2014), it was determined that depressive individuals try to derive the satisfaction which they cannot get in real life from close relationships which they establish in Facebook. It is stated that a similar situation is true for adolescents living social anxiety or lonely adolescents (Sheldon, 2008). However, in this study, no findings verifying the social compensation hypothesis could be obtained. For this reason, it can be stated that there is a need for studies examining the relationships between the attachment styles and the Facebook addiction based on different hypotheses (e.g., the stimulation hypothesis; Valkenburg \& Peter, 2007). 
In conclusion, the findings obtained from this study did not verify the social compensation hypothesis. The social compensation hypothesis put forwards that when individuals do not feel themselves secure in their social relationships in real life, they may spend too much time on using social networking sites to compensate this and this may result in addiction (Hong et al., 2014). For social networking sites provide individuals with many opportunities facilitating the establishment of close relationship (hiding identity, etc.). However, the findings obtained from this study indicated that individuals with the dismissing and fearful attachments styles preferring to withdraw from other individuals in real life were not at risk in terms of Facebook addiction. The finding that using Facebook for social compensation led to increase in the feeling of loneliness within the course of time (Teppers, Luyckx, Klimstra, \& Goosens, 2014) makes the findings obtained from this study more understandable. Moreover, in the mentioned study, it was also determined that using Facebook with the aim of making new friends increased the satisfaction derived from peer relationships. In this context, it can be stated that carrying out new studies examining the relationships between the attachment styles and the Facebook addiction by considering the factors leading to use of Facebook (for example, receiving positive feedback, self-presentation, entertainment, etc.) will make it possible to obtain healthier results.

This study has various limitations. Firstly, this study includes university students. This restricts the generalizability of the findings. Secondly, since the cross-sectional design was used in the study, findings related to causality could not be obtained. For this reason, it can be stated that longitudinal studies are needed. Finally, in this study, the measurement tools based on self-report were used. For this reason, carrying out new studies based on different techniques (for example, interview, etc.) will make contribution to the detailed evaluation of Facebook.

Despite all these limitations, this study makes a serious contribution to the field. Focusing on the attachment styles, this study put forward important findings in the explanation of individuals' using Facebook in an uncontrolled way. Within the scope of this study, various suggestions can be made. Firstly, if the relationships between the attachment styles and the Facebook addiction are examined via new studies considering such variables as time spent in Facebook, reasons for using Facebook, attitudes toward Facebook, loneliness, personality, etc., more comprehensive findings can be obtained. Secondly, in this study, the attachment styles were examined by using the Relationship Scales Questionnaire. In this context, carrying out new studies measuring the attachment styles via using different measurement tools (e.g., Attachment to Parents and Friends Inventory, Experiences in Close Relationships Inventory) will make it possible to obtain new findings related to these relationships. Lastly, it can be stated that preparing intervention programs by psychological counseling services will be useful in terms of preventing Facebook addiction in university students. It can be stated that these intervention programs should especially include elements increasing individuals' problem solving skills and supporting their interpersonal relationships (Akbaba, 2012).

\section{Conclusion}

To the author's knowledge, the current study is among the first to investigate the relationships between attachment styles and Facebook addiction. Furthermore, the results of this study hold important implications for researchers interested in identifying university students most at risk for Facebook and other social networking sites addiction. University students who use Facebook to compensate for their shortcomings in low self-worth and poor social skills are more likely to be Facebook addiction. The social compensation hypothesis postulates that these university students more adaptive ways of coping with difficulties in real life by using Facebook in order to establish social relationships and receive positive feedback. Although Facebook is utilized to compensate weakness in real life (McKenna et al., 2002), this study indicated that Facebook usage is only useful in terms of compensating shortcomings in real life, if people have preoccupied attachment style.

\section{References}

Akbaba, S. (2012). Psikolojik sağglı̆̆ koruyucu rehberlik. Ankara: Pegem Akademi.

Akın, A., Demirci, İ., Akın, Ü., Ocakçı, H., Akdeniz, C., \& Akbaş, Z. Ş. (2013). Turkish version of the Facebook addiction scale. In 13th European congress of psychology, June, 9-12, Stockholm, Sweeden.

Andreassen, C. S., Torsheim, T., Brunborg, G. S., \& Pallesen, S. (2012). Development of a Facebook Addiction Scale. Psychological Reports, 110(2), 501-517. http://dx. doi.org/ 10.2466/02.09.18.PR0.110.2.501-517

Arslan, E., Arslan, E., \& Ar1, R. (2012). An investigation of interpersonal problem solving approaches with respect to attachment styles .Educational Sciences: Theory \& Practice, 12(1), 7-23.

Bartholomew, K., \& Horowitz, L. M. (1991). Attachment styles among young adults: A test of a four-category model. Journal of Personality and Social Psychology, 61, 226-244. http://dx.doi.org/10.1037/0022-3514.61.2.226

Bevan, J. L., Gomez, R., \& Sparks, L. (2014). Disclosures about important life events on Facebook: Relationship with stress and quality of life. Computers in Human Behavior, 39, 249-253. http://dx. doi.org/10.1016/j.chb.2014.07.021 
Bowlby, J. (1977). The making and breaking of affectional bonds: Aetiology and psychopathology in the light of attachment theory. British Journal of Psychiatry, 130, 201-210. http://dx. doi.org/ 10.1192/bjp.130.3.201

Bowlby, J. (1980). Attachment and loss, Vol. II. Seperation: Anxiety and anger. New York: Basic Books.

Boyd, D. M., \& Ellison, N. B. (2007). Social network sites: Definition, history, and scholarship. Journal of Computer-Mediated Communication, 13(1), 210-230. http://dx. doi.org/ 10.1111/j.1083-6101.2007.00393.x

Brennan, K. A., \& Bosson, J. K. (1998). Attachment-style differences in attitudes toward and reactions to feedback from romantic partners: An exploration of the relational bases self-esteem. Personality and Social Psychology Bulletin, 24, 699-714. http://dx. doi.org/10.1177/0146167298247003

Cao, F., \& Su, L. (2007). Internet addiction among Chinese adolescents: Prevalence and psychological features. Child Care and Health and Development, 33(3), 275-281.

Chou, H. T. C., \& Edge, N. (2012). "They are happier than having better lives than I am.”: The impact of using Facebook on perceptions of others' lives. Cyberpsychology, Behavior, and Social Networking, 15(2), 117-121. http://dx. doi.org/10.1089/cyber.2011.0324

Cohen, J. (1988). Statistical power analysis for the behavioral sciences (2nd ed.). Hillsdale, NJ: Lawrance Earlbaum Associates.

Debernardi, N. R. (2012). Problematic internet use: Exploring the roles of attachment and social competency. Ph.D. dissertation, University of Missouri-Kansas City, Kansas City, Missouri.

Deniz, M. E. (2006). Ergenlerde bağlanma stilleri ile çocukluk istismarları ve suçluluk-utanç arasındaki ilişki. Eurasian Journal of Educational Research, 22, 89-99.

Facebook (2015). Company info. Palo Alto, CA: Facebook. Retrieved from http://newsroom.fb.com/company-info/

Foregger, S. (2008). Uses and gratifications of Facebook.com. Ph.D. dissertation, Michigan State University, Michigan.

Fraley, R. C., Waller, N. G., \& Brennan, K. A. (2000). An item-response theory analysis of self-report measures of adult attachment. Journal of Personality and Social Psychology, 78, 350-365. http://dx.doi.org/ 10.10370022-3514.78.2.350

Gallitto, E., \& Leth-Steensen, C. (2015). Autistic traits and adult attachment styles. Personality and Individual Differences, 79, 63-67. http://dx. doi.org/10.1016/j.paid.2015.01.032

Griffin, D. W., \& Bartholomew, K. (1994). The metaphysics of measurement: The case of adult attachment. In K. Bartholomew \& D. Perlman (Eds.), Advances in personal relationships. 5, Attachment process in adulthood (pp.17-52). London: Kingsley.

Gulati, D. (2011). Re: Facebook is making us miserable [Web log message]. Retrieved from http://blogs.hbr.org/cs/2011/12/facebook_is_making_us_miserabl.html

Gündüz, B. (2013). The contributions of attachment styles, irrational beliefs and psychological symptoms to the prediction of cognitive flexibility. Educational Sciences: Theory \& Practice, 13(4), 2071-2085. http://dx. doi.org/ 10.12738/estp.2013.4.1702

Hart, J., Nailling, E., Bizer, G. Y., \& Collins, C. K. (2015). Attachment theory as a framework for explaining engagement with Facebook. Personality and Individual Differences, $77,33-40 . \quad \mathrm{http}: / / \mathrm{dx}$. doi.org/10.1016/j.paid.2014.12.016

Hazan, C., \& Shaver, P. R. (1987). Romantic love conceptualized as an attachment process. Journal of Personality and Social Psychology, 52, 511-524.

Hong, F. Y., Huang, D. H., Lin, H. Y., \& Chiu, S. L. (2014). Analysis of the psychological traits, Facebook usage, and Facebook addiction model of Taiwanese university students. Telematics and Informatics, 31, 597-606. http://dx. doi.org/10.1016/j.tele.2014.01.001

Hughes, D. J., Rowe, M., Batey, M., \& Lee, A. (2012). A tale of two sites: Twitter vs. Facebook and the personality predictors of social media usage. Computers in Human Behavior, 28(2), 561-569. http://dx. doi.org/10.1016/j.chb.2011.11.001

Huntsinger, E. T., \& Luecken, L. J. (2004). Attachment relationships and health behavior: The mediational role of self-esteem. Psychology and Health, 19(4), 515-526. http://dx. doi.org/ 10.1080/0887044042000196728

İlhan, T. (2012). Loneliness among University Students: Predictive Power of Sex Roles and Attachment Styles on Loneliness. Educational Sciences: Theory \& Practice, 12(4), 2377-2396. 
Joinson, N. A. (2008). Looking at', 'Looking up' or 'Keeping up with' People? Motives and uses of Facebook. CHI 2008 Proceedings (pp. 1027-1036).

Karaiskos, D., Tzavellas, E., Balta, G., \& Paparrigopoulos, T. (2010). Social network addiction: a new clinical disorder? European Psychiatry, 25(1), 855. http://dx. doi.org/10.1016/S0924-9338(10)70846-4

Kim, J., \& Haridakis, P. M. (2009). The role of Internet user characteristics and motives in explaining three dimensions of Internet addiction. Journal of Computer-Mediated Communication, 14(4), 988-1015. http://dx.doi.org/ 10.1111/j.1083-6101.2009.01478.x.s

Kim, Y., Sohn, D., \& Choi, S. M. (2011). Cultural difference in motivations for using social network sites: A comparative study of Amerikan and Korean college students. Computers in Human Behavior, 27, 365-372. http://dx. doi.org/10.1016/j.chb.2010.08.015

Kross, E., Verduyn, P., Demiralp, E., Park, J., Lee, D. S., Lin, N., Shablack, H., Jonides, J., \& Ybarra, O. (2013). Facebook use predicts declines in subjective well-being in young adults. PLoS ONE, 8(8), e69841. http://dx. doi.org/ 10.1371/journal.pone.0069841

Kuss, D. J., Griffiths, M. D., \& Binder, J. F. (2013). Internet addiction in students: Prevalence and risk factors. Computers in Human Behavior, 29(3), 959-966. http://dx. doi.org/10.1016/j.chb.2012.12.024

Kuss, D., \& Griffiths, M. (2011). Online social networking and addiction-A review of the psychological literature. International Journal of Environmental Research and Public Health, 8, 3528-3552.

Lavin, M. J., Yuen, C. N., Weinman, M., \& Kozak, K. (2004). Internet dependence in the collegiate population: the role of shyness. CyberPsychology \& Behavior, 7(4), 379-383. http://dx. doi.org/10.1089/cpb.2004.7.379

Lee, J. S., \& Koo, H. J. (2015). The relationship between adult attachment and depression in Korean mothers during the first 2 years postpartum: A moderated mediation model of self-esteem and maternal efficacy. Personality and Individual Differences, 79, 50-56. http://dx. doi.org/10.1016/j.paid.2015.01.021

Lee, Z. W. Y., Cheung, C. M. K., \& Thadani, D. R. (2012). An investigation into the problematic use of Facebook. In 45th Hawaii international conference on system sciences.

Leiter, M. P., Day, A., \& Price, L. (2015). Attachment styles at work: Measurement, collegial relationships, and burnout. Burnout Research, 2, 25-35. http://dx. doi.org/10.1016/j.burn.2015.02.003

Lin, M. P., Ko, H. C., \& Wu, J. Y. (2011). Prevalence and psychosocial risk factors associated with internet addiction in a nationally representative sample of college students in Taiwan. Cyberpsychology, behavior, and social networking, 14(12), 741-746. http://dx. doi.org/ 10.1089/cyber.2010.0574

McKenna, K. Y. A., Green, A. S., \& Gleason, M. E. J. (2002). Relationship formation on the internet: what's the big attraction? Journal of Social Issues, 58, 9-31. http://dx.doi.org/10.1111/1540-4560.00246.

Mikulincer, M., \& Florian, V. (1995). Appraisal of and coping with a real-life stressful situation: The contribution of attachment styles. Personality and Social Psychology Bulletin, 21, 406-414. http://dx. doi.org/ 10.1177/0146167295214011

Mikulincer, M., \& Shaver, P. R. (2007). Attachment in adulthood: Structure, dynamics, and change. New York, NY: Guilford Press.

Odacı, H., \& Çıkrıkçı, Ö. (2014). Problematic internet use in terms of gender, attachment styles and subjective well-being in university students. Computers in Human Behavior, 32, 61-66. http://dx. doi.org/10.1016/j.chb.2013.11.019

Oldmeadow, J. A., Quinn, S., \& Kowert, R. (2013). Attachment style, social skills, and Facebook use amongst adults. Computers in Human Behavior, 29(3), 1142-1149. http://dx. doi.org/10.1016/j.chb.2012.10.006

Oshri, A., Sutton, T. E., Clay-Warner, J., \& Miller, J. D. (2015). Child maltreatment types and risk behaviors: Associations with attachment style and emotion regulation dimensions. Personality and Individual Differences, 73, 127-133.

Papacharissi, Z., \& Mendelsohn, A. (2011). Toward a new(er) sociability: Uses, gratifications and social capital on Facebook. In S. Papathanassopoulos (Ed.), Communication and society. Media perspectives for the 21st century. Concepts, topics and issues (pp. 212-230). New York: Routledge.

Park, L. E., Crocker, J., \& Mickelson, K. D. (2004). Attachment styles and contingencies of self-worth. Personality and Social Pscyhology Bulletin, 30, 1243-1254. http://dx. doi.org/ 10.1177/0146167204264000.

Pepping, C. A., O’Donovan, A., Zimmer-Gembeck, M. J., \& Hanisch, M. (2015). Individual differences in attachment 
and eating pathology: The mediating role of mindfulness. Personality and Individual Differences, 75, 24-29. http://dx. doi.org/10.1016/j.paid.2014.10.040

Sagioglou, C., \& Greitemeyer, T. (2014). Facebook's emotional consequences: Why Facebook causes a decrease in mood and why people still use it. Computers in Human Behavior, 35, 359-363.

Satıcı, B., Sarıcalı, M., Satıcı, S. A., \& Eraslan-Çapan, B. (2014). Social competence and psychological vulnerability as predictors of Facebook addiction. Studia Psychologica, 56(4), 301-308.

Satıc1, S. A., \& Uysal, R. (2015). Well-being and problematic Facebook use. Computers in Human Behavior, 49, 185-190. http://dx. doi.org/10.1016/j.chb.2015.03.005

Shaver, P. R., \& Hazan, C. (1993). Adult romantic attachment: Theory and evidence. In D. Perlman \& W. Jones (Eds.), Advances in personal relationships (pp. 29-70). London: Jessica Kingsley.

Sheldon, P. (2008). The relationship between unwillingness-to-communicate and students' Facebook use. Journal of Media Psychology, 20, 67-75. http://dx. doi.org/10.1027/1864-1105.20.2.67

Şimşek, Ö. F. (2011). Structural relations of personal and collective self-esteem to subjective well-being: Attachment as moderator. Social Indicator Research, 110(1), 219-236. DOI 10.007/s11205-011-99-27-1

Sümer, N., \& Güngör, D. (1999). Psychometric evaluation of adult attachment measures on Turkish samples and a cross-cultural comparison. Turkish Journal of Psychology, 14(43), 71-109.

Tabachnick, B. G., \& Fidell, L. S. (2001). Using multivariate statistics. Boston: Allyn and Bacon.

Teppers, E., Luycx, K., Klimstra, T. A., \& Goossens, L. (2014). Loneliness and Facebook motives in adolescence: A longitudinal inquiry into directionality of effect. Journal of Adolescence, 37, 691-699.

Valkenburg, P. M., \& Peter, J. (2007). Preadolescents' and adolescents' online communication and their closeness to friends. Developmental Psychology, 43, 267-277. http://dx.doi.org/10.1037/0012-1649.43.2.267

\section{$(\mathrm{cc}) \mathrm{EY}$}

This work is licensed under a Creative Commons Attribution 3.0 License. 